\title{
Ecological Aspects of Phebotomine (Diptera, Psychodidae) in an Endemic Area of Tegumentary Leishmaniasis in the Northeastern Argentina, 1993-1998
}

\author{
Oscar D Salomón ${ }^{+}$, Gustavo C Rossi*, Gustavo R Spinelli***
}

\begin{abstract}
Centro Nacional de Diagnóstico e Investigación en Endemo-Epidemias, Av. Paseo Colón 568, 1063, Buenos Aires, Argentina *Centro de Estudios Parasitológicos y de Vectores, La Plata, Argentina **Facultad de Ciencias Naturales y Museo, Universidad Nacional de La Plata, La Plata, Argentina
\end{abstract}

The first epidemic tegumentary leishmaniasis' outbreak in the province of Misiones was recorded in 1998, in the locality of Puerto Esperanza. Phlebotominae collected in the region, previously or simultaneously to the outbreak (September 1993-December 1998) showed that the species Lutzomyia intermedia s. 1. was prevalent (94\%, n 6,150) at all the sites sampled with miniature light trap (10) and Shannon trap (3). L. pessoai, L. whitmani, L. migonei, L. shannoni, L. fischeri, L. misionensis, Brumptomyia avellari and B. guimaraesi were also captured. Sand fly distribution in time and space suggests that in the province of Misiones (1) the species already present before 1990 could give rise to the epidemic by the density/dispersion fluctuation of their local populations; (2) the abundance of $\mathrm{L}$. intermedia s. 1. was associated with environments with ecotones of primary-secondary vegetation, close to water bodies and with moderate human disturbance; (3) this species showed, towards the end of 1997, peaks of exceptional abundance, subsequent to rainfall peaks in 1996. This increase in abundance of potential vector sand fly populations close to houses with colonizable surroundings could have generated the 1998 epidemic outbreak.

Key words: Lutzomyia intermedia - Lutzomyia whitmani - vector ecology - leishmaniasis - Argentina

The first autochthonous cases of tegumentary leishmaniasis were recorded in Argentina in 1916 (Bernasconi 1928, Villalonga 1963). Until 1980, 43 cases/year, coming from the territory north of parallel $28^{\circ}$, were reported in the whole country (Bernasconi 1930, Cedillos \& Walton 1988). In 1985, an epidemic outbreak due to Leishmania (Viannia) braziliensis in the province of Salta, NW of Argentina, occurred, followed by outbreaks in the rest of the endemic territory (Villafañe et al. 1988, Grimaldi et al. 1989, Campanini et al. 1993, Salomón 1993, 1998, Sosa Estani et al. 1993, 1998, Salomón et al. 1995, Sosa Estani 1998). The province of Misiones is located in the NE of Argentina, on the frontier with Brazil and Paraguay, the primary vegetation belongs to the subtropical forest (Cabrera 1971). Mean cases/year in the province of Misiones were 7.2 for the period 1954/1974, 0.25 in 1975/ 1995, 5.5 in 1996/1997 and 205 cases in 1998 (incidence rate 25.6/100,000). In 1998, $98 \%$ of these cases came from Puerto Esperanza, Department of Iguazú (Epid Dir, pers. commun.).

Sporadic captures of Phlebotominae, carried out in Misiones before 1960, demonstrated the presence of Lutzomyia alphabetica, L. intermedia, L. longipalpis, $L$. migonei, L. misionensis, L. monticola, L. pascalei, $L$. pessoai, L. quinquefer, L. shannoni, and L. whitmani

OD Salomón and GR Spinelli are members of "Carrera del Investigador Científico", Conicet

${ }^{+}$Corresponding author. Fax: +54-11-4331.2536. E-mail: danielsalomon@hotmail.com

Received 20 March 2001

Accepted 23 August 2001
(Romaña \& Abalos 1949, Bejarano \& Duret 1950, Duret 1952, Castro 1959a,b, Del Ponte 1960). According to Marcondes et al. (1998a,b) the taxon that occur in Argentina is $L$. neivai instead of $L$. intermedia, so in this text $L$. intermedia means actually L. intermedia s. $l$.

This study shows the results of captures of Phlebotominae carried out in Misiones between 1993 and 1998, at sites with and without records of previous cases. Probable entomological causes of the epidemic outbreak are inferred from the results with the objective of contributing to the design of possible control strategies. Characteristics of the epidemic outbreak will be the subject of a future article.

\section{MATERIALS AND METHODS}

Phlebotominae were collected at 10 sites along the Paraná river (Fig. 1), corresponding to greatly modified environments with open vegetation (A, D, E, J), modified environments with secondary vegetation and isolated specimens of primary vegetation (C, F, H, I), and less modified environments or transitional environments with thickly vegetation $(B, G)$. Two $C D C$ miniature light traps were used in parallel per site, both with $\mathrm{CO}_{2}(500 \mathrm{ml} / \mathrm{h})$, one of them dry and the other with $70 \%$ alcohol, placed $1.5 \mathrm{~m}$ above the ground. Captures were carried out monthly, uninter-rumptedly during $24 \mathrm{~h}$, from September 1993 to December 1998. The objective of the design was not a longitudinally study of Phlebotominae but to sample other insects, so that the captures were discontinuous and, the effort different among sites. In February 1998, captures in Eldorado ( $26^{\circ} 23^{\prime} \mathrm{LS}-54^{\circ} 39^{\prime} \mathrm{LW}$ ), Andresito ( $25^{\circ} 40^{\prime} \mathrm{LS}$ $54^{\circ} 03^{\prime} \mathrm{LW}$ ) and Cerro Azul ( $\left.27^{\circ} 43^{\prime} \mathrm{LS}-55^{\circ} 29^{\prime} \mathrm{LW}\right)$ were carried out for two consecutive days per site, using a modified Shannon trap, from $6.30 \mathrm{pm}$ to $9 \mathrm{pm}$ (Salomón et al. 


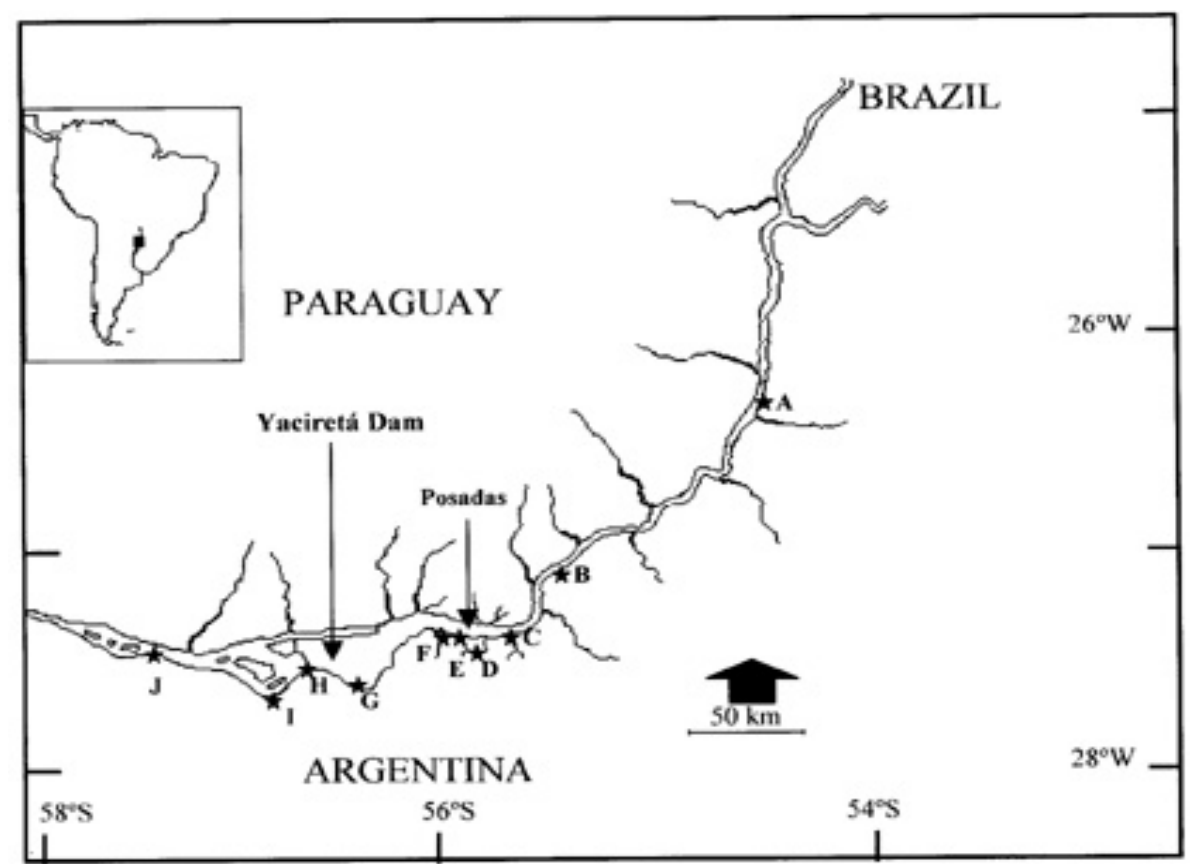

Fig.1: capture sites by CDC miniature light trap in the province of Misiones (A-F) and Corrientes (H-J), Argentina, 1993-1998. A: Montecarlo; B: Corpus; C: Candelaria; D: Zaiman; E: Mártires; F: Itaembé; G: Santa Tecla; H: Ituzaingó; I: Villa Olivari; J: Ita-Ibaté

1995, Salomón 1997). Andresito had recorded human cases of leishmaniasis in 1996/1997 and Cerro Azul in 1990/1995. Phlebotominae were processed and identified according to Young and Duncan (1994).

Meteorological data were obtained from the forest stations of APSA Libertad, INTA Cerro Azul and EBY Ituzaingó. APSA data were the only overplotted as the data did not show any significant differences among sources.

For their statistical analysis, monthly capture data, by station or by species, were transformed into proportions of total captures.

\section{RESULTS}

Phlebotominae (n 6,150) were captured using light minitraps at the 10 sampled sites, and in $36.6 \%$ of the 232 nights/capture (Table I). L. intermedia was represented in $98.7 \%$ of the captures, with at least one individual in each of them. At Corpus station $91 \%$ of the 5,781 specimens of this species were captured (Table II). The annual collections and records of mean temperature and rainfall were plotted per site (Fig. 2). Mean temperature was relatively uniform over the year and during the years studied, with a minimum between June and July (May in 1995). Rainfall was trimodal in 1992-1994 and 1996, and bimodal in 1995, 1997 and 1998. In November 1994 and October 1996, accumulated monthly rainfall higher than $400 \mathrm{~mm}$ was recorded.

No specimens of Phlebotominae were captured between September 1993 and February 1994 at the stations sampled. In Montecarlo, Posadas and Ituzaingó (Fig. 2), maximum captures of $L$. intermedia took place in MayJuly and another capture, significantly more important, occurred in August 1995 (in Ituzaingó, in January and March 1996). Santa Tecla had more uniform captures during the study period, but again with a maximum in August 1995. Results in Corpus were qualitatively different from the others: from February 1996 to 1998 captures of $L$. intermedia s. $l$. exceeded 200 specimens/month in five occasions, reaching a maximum of 1,508 specimens in November 1997. Corpus presented captures in all months without a rainfall peak, except during the abnormal profile of 1997 (with rains in August).

The other collected species were $L$. pessoai, $L$. whitmani, L. migonei, L. shannoni, L. fischeri, $L$. misionensis, Brumptomyia avellari and B. guimaraesi.

TABLE I

Phlebotominae relative abundance by species, captured with miniature light trap, in Santa Tecla, Corpus, and the remaining capture sites (Others), Argentina, September 1993 - December 1998

\begin{tabular}{lccc}
\hline Species & Santa Tecla (\%) & Corpus (\%) & Others (\%) \\
\hline L. intermedia & $123(32.5)$ & $5,265(98.1)$ & $393(97.1)$ \\
L. pessoai & $7(1.8)$ & $19(0.4)$ & $3(0.7)$ \\
L. fischeri & $11(2.9)$ & $9(0.2)$ & 0 \\
L. migonei & $7(1.8)$ & 0 & 0 \\
L. shannoni & $6(1.6)$ & 0 & 0 \\
L. misionensis & $1(0.3)$ & 0 & 0 \\
L. whitmani & 0 & $60(1.1)$ & $3(0.7)$ \\
B. avellari & $67(17.7)$ & 0 & $6(1.5)$ \\
B. guimaraesi & $157(41.4)$ & $13(0.2)$ & 0 \\
\hline Total & $379(100)$ & $5,366(100)$ & $405(100)$
\end{tabular}

L: Lutzomyia; B: Brumptomyia 


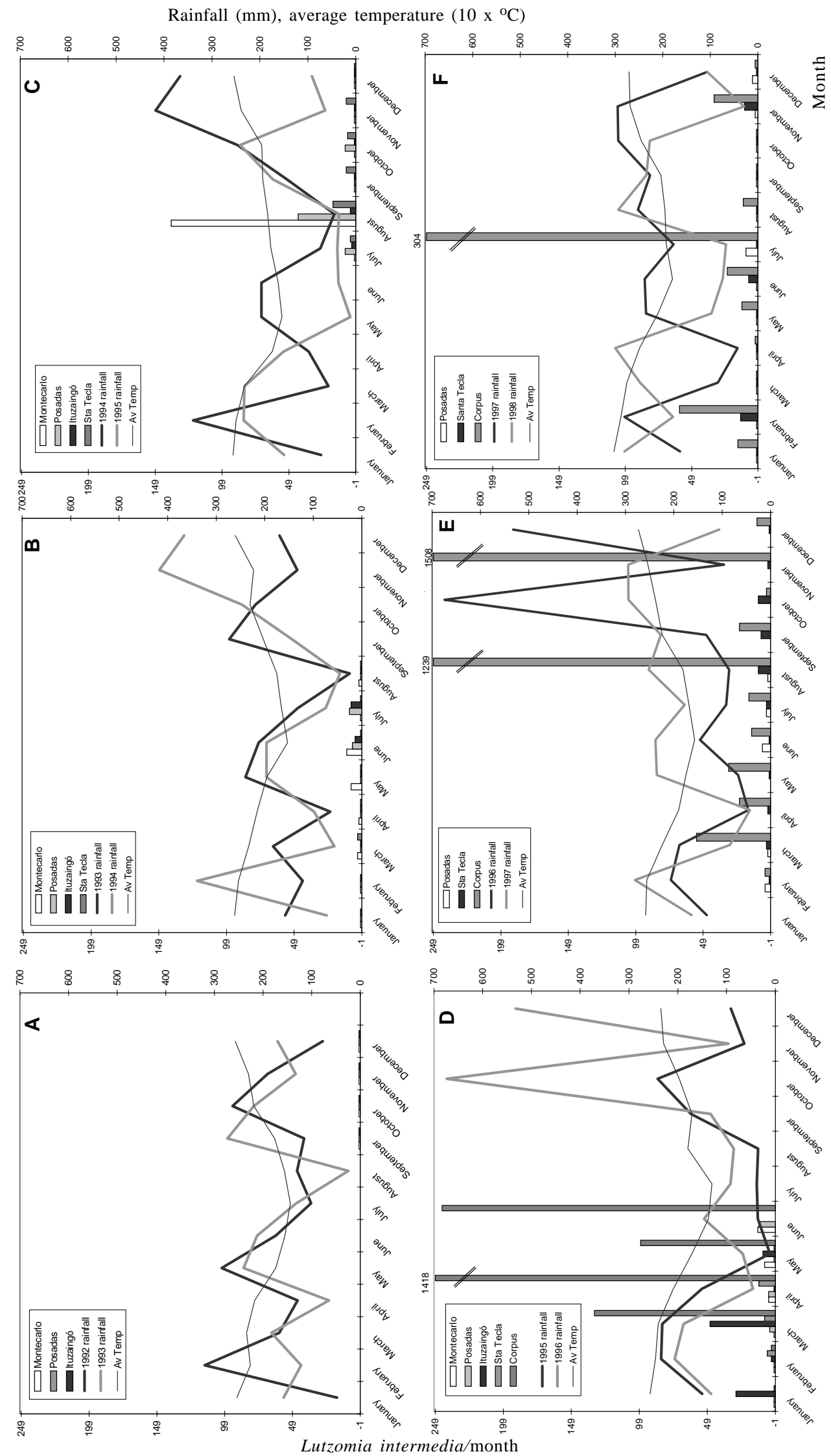

Fig. 2: Lutzomyia intermedia abundance, average temperature $\left(10 \mathrm{x}{ }^{\circ} \mathrm{C}\right)$ and rainfall $(\mathrm{mm})$ by month and site, Misiones and Corrientes, Argentina. A: 1993, B: 1994, C: 1995, D: 1996, E: 1997, F: 1998 
TABLE II

Lutzomyia intermedia captured by CDC miniature light trap, by locality in Misiones and Corrientes provinces, Argentina, September 1993 - December 1998

\begin{tabular}{lccccc}
\hline & Total & Females $(\%)$ & Specimens/day & Positive traps $(\%)$ & Days sampled \\
\hline Montecarlo $^{a}$ & 181 & 80.1 & 5 & 30.6 & 36 \\
Posadas $^{b}$ & 111 & 69.4 & 1.5 & 25.3 & 75 \\
Ituzaingó $^{c}$ & 101 & 79.2 & 1.9 & 5.1 & 53 \\
Santa Tecla $_{\text {Corpus }}$ & 123 & 77.2 & 188 & 52.5 & 40 \\
Total & 5,265 & 84.4 & 24.9 & 36.3 & 28 \\
\hline
\end{tabular}

$a$ : traps at Montecarlo and Candelaria included; $b$ : traps at Mártires, Itaembé and Zaiman included; $c$ : traps at Ituzaingó, Villa Olivari and Ita-Ibaté included.

These species were found together with L. intermedia on 24 occasions, and only in two captures, those made at Santa Tecla and Posadas (Mártires Stream), B. guimaraesi and $L$. pessoai were found alone. Captures of $L$. intermedia simultaneously with other species were customary in Corpus and Santa Tecla (Table I), but only ocurred once in Mártires (L. pessoai), Itaembé (L. whitmani), Candelaria and Ituzaingó (B. avellari).

Using the modified Shannon trap in Eldorado, on the banks of the Paraná river, without any records of previous cases, and in Cerro Azul, with historical records, no Phlebotominae were obtained. On the other hand, in Andresito, in a thickly forested peridomicile close to a recent human case, 35 Phlebotominae, 23 L. intermedia s. l. $(65.7 \%)$ (male: female 1:1), 9 L. whitmani $(25.7 \%)$ (male: female 1:2) and 3 females of $L$. shannoni (8.6\%) were captured.

\section{DISCUSSION}

Phlebotominae are cited by 11 species in the literature for the provinces of Misiones and Corrientes, captured mainly between 1947 and 1951 (Bejarano \& Duret 1950, Castro 1959a,b, Del Ponte 1960, Borda et al. 1998). Six of these species are reported in this study; another four of them (L. longipalpis, L. quinquefer, L. monticola and $L$. cortelezzii) were collected after 1998 (unpublished), and the other two, cited for single specimens from 1948, were not found (L. pascalei, L. alphabetica). Captures of $L$. fischeri, B. avellari and B. guimaraesi are recent (Spinelli et al. 1999); the rarity of the first and the little attraction for light and null anthropophily of Brumptomyia (Young \& Arias 1992), would be the cause of their absence in previous records.

The presence of $L$. intermedia was observed throughout the year, showing peaks in later autumn (1994), others of higher magnitude associated to relatively scarce rainfall (1995, 1996, 1997, March - 1998), and maximum peaks related to exceptional rainfall in the season or in the previous years (1996 and 1997). Regarding the lower thermic amplitude and the more temperate winter of Misiones, the annual pattern was consistent with that obtained for this species in the focus of leishmaniasis in the province of Salta. In this latter, abundance was associated to temperate seasons with moderate rain, to the years after one of exceptional precipitation, and to the fact that the risk of transmission of leishmaniasis is higher in autumn (Salomón 1997).
The historical area of dispersion of Phlebotominae in Misiones has suffered, in the last decades, an intense process of deforestation and reforestation, as well as environmental modifications due to dam construction, both phenomena associated in the literature with vector concentration, microfoci of parasite circulation and epidemic outbreaks (Lainson 1989, Gomes et al. 1990, Mott et al. 1990, Walsh et al. 1993, Tolezano 1994). Captures were carried out on environment associated with the gallery forest of the Paraná river or smaller streams and in ecotones between the primary forest and deforested areas, where the concentration/abundance of vectors could be increased by periodic inundations (Salomón 1997). In the greatly modified environment with open vegetation (Montecarlo, Candelaria, Posadas) few captures were obtained (the most productivity being obtained in the residual forest of Candelaria and Itaembé), with peaks in dry winters. Unseasonable peaks in Ituzaingó could be due to anthropic action or to a non-recorded local meteorological phenomenon. In the less modified environment or transitional environment with thick vegetation (Corpus, Santa Tecla) the captures were more numerous, and because there was very little human interference the meteorological variables could be better observed. The better preserved forest and the greater distance from human settlements could explain the higher magnitude of the captures in Corpus. The abundance of $B$. guimaraesi in Santa Tecla requires a focal investigation into potential host dynamics and spacial distribution.

The literature records isolations of $L$. (V.) braziliensis from L. whitmani, L. intermedia, L. migonei and L. pessoai (Young \& Arias 1992). Captures in Andresito allow one to obtain a profile of anthropophagic species at a site of transmission prior to the outbreak, simultaneously with captures with the light trap. The prevalent species was $L$. intermedia, followed by L. whitmani. L. intermedia was considered as a possible vector of $L$. (V.) braziliensis during recent outbreaks in modified environments; $L$. whitmani has been its primary vector, responsible for the traditional sporadic transmission, and associated with work in the forest (Lainson \& Shaw 1979, Gomes et al. 1990, Pereira \& Hoch 1990, Rangel et al. 1990, 1992, Stolf et al. 1993, Gomes 1994, Queiroz et al. 1994, Tolezano 1994, Salomón 1997, Salomón \& Zaidemberg 1997).

Results of sand fly captures have been evaluated from historical, meteorological, anthropic and microecological 
variables. In conclusion, the fauna of Phlebotominae of the province of Misiones has not suffered qualitative changes at a macrogeographical level, which would lead to an epidemic outbreak. However, metapopulations of already present species can colonize new environments or even became extinct which would modify their local density and spacial distribution. L. intermedia, possible vector of $L$. (V.) braziliensis, was the prevalent species in the captures in Misiones, and its abundance was associated with thickly forested environments of primary secondary ecotones and the proximity of bodies of water. These conditions can be heightened or nullified by microecological characteristics provoked by anthropic activity. $L$. intermedia, in proper environments, showed peaks of exceptional abundance, subsequent to rainfall peaks in the previous season/year, as has already been observed in the epidemic focus of the northwestern Argentina (Salomón 1997). This phenomenon, observed in Misiones towards the end of 1997, if it occurred in vector populations infected with Leishmania close to a human settlement, with ecological conditions which allowed colonization of the surroundings of the house, could have generated the 1998 epidemic outbreak.

\section{REFERENCES}

Bejarano JRF, Duret JP 1950. Contribución al conocimiento de los flebótomos argentinos (Diptera:Psychodidae). Rev Sanidad Militar Argentina 49: 327-336.

Bernasconi VE 1928. Contribución al estudio de la distribución geográfica de la leishmaniosis en la República Argentina. Bol Inst Clin Quirug Buenos Aires 15: 325-328.

Bernasconi V 1930. Consideraciones sobre el censo de leishmaniosis. V Reunión Soc Pat Reg Norte 1: 590-602.

Borda EC, Rea MJF, Rosa JR, Mosqueda LA, Gené CM 1998. Investigaciones sobre leishmaniosis en la provincia de Corrientes. In AC Seijo, OP Larghi, MO Espinosa, M Rivas, M Sabattini (eds), Zoonosis y Enfermedades Emergentes, Asoc Arg Zoonosis, Buenos Aires, p. 193-198.

Cabrera AL 1971. Fitogeografía de la República Argentina. Bol Soc Arg Bot 14: 1-50.

Campanini AR, Sinagra A, Saravia N, Arévalo J, Luna C, Sosa Estani S, Salomón D, Segura EL 1993. Caracterización in vitro de aislados de Leishmania de pacientes de Salta. Medicina (Buenos Aires) 53 (Supl.1): 81.

Castro M 1959a. Notas sobre Flebotominae argentinos con la descripción de Flebotomus misionensis n. sp. (Diptera: Psychodidae). In JRF Bejarano, E del Ponte, RN Orfila (eds), Primeras Jornadas Entoepidemiológicas Argentinas, La Prensa Médica, Buenos Aires, p. 331-334.

Castro M 1959b. Diptera: Psychodidae-Flebotominae. In JRF Bejarano, E del Ponte, RN Orfila (eds), Primeras Jornadas Entoepidemiológicas Argentinas, La Prensa Médica, Buenos Aires, p. 545-546.

Cedillos RA, Walton BC 1988. Leishmaniasis: special situations in other areas of the Americas. In IDRC CRDI CIID, Research on Control Strategies for the Leishmaniasis, Manuscript Report 184e, IRDC, Ottawa, p.156-161.

Del Ponte E 1960. Distribución y conocimiento actual de la leishmaniosis en la Argentina. Primer Congreso Sudamericano de Zoología T1, p. 211-241.

Duret JP 1952. Notas sobre flebótomos argentinos. Rev de Sanidad Militar Argentina 51: 534-536.

Gomes AC 1994. Sand fly vectorial ecology in the State of São Paulo. Mem Inst Oswaldo Cruz 89: 457-460.
Gomes AC, Coutinho SG, Paim GV, Oliveira SMO, Galati EAB, Nunes MP, Capinzaiki AN, Yamamoto YI, Rotter P 1990. Aspectos ecológicos da leishmaniose tegumentar americana. 8. Avaliação da atividade enzoótica de Leishmania (Viannia) braziliensis, em ambiente florestal e peridomiciliar, Região do Vale do Ribeira, Estado de São Paulo, Brasil. Rev Inst Med Trop São Paulo 32: 105-115.

Grimaldi G, Tesh RB, McMahon-Pratt D 1989. A review of the geographic distribution and epidemiology of leishmaniasis in the New World. Am J Trop Med Hyg 41: 687-725.

Lainson R 1989. Demographic changes and their influence on the epidemiology of the American leishmaniases. In MW Service, Demography and Vector-Borne Diseases, CRC Press, Boca Raton, p. 85-106.

Lainson R, Shaw JJ 1979. The role of animals in the epidemiology of South American leishmaniasis. In WHR Lumsden, DA Evans (eds), Biology of the Kinetoplastida, Academic Press, London, Vol. 2, p. 1-116.

Marcondes CB, Lozovei AL, Vilela JH 1998a. Distribuição geográfica de flebotomíneos do complexo Lutzomyia intermedia (Lutz \& Neiva, 1912). Rev Soc Bras Med Trop 31: $51-58$.

Marcondes CB, Lozovei AL, Galati EA 1998b. Variações regionais e interespecíficas adicionais na morfologia de insetos do complexo Lutzomyia intermedia (Lutz \& Neiva, 1912) (Diptera, Psychodidae, Phlebotominae). Rev Saúde Pública 32: 519-525.

Mott KE, Desjeux P, Moncayo A, Raanque P, de Raadt P 1990. Parasitic diseases and urban development. Bull WHO 68: 691-698.

Pereira IR, Hoch A 1990. Lutzomyia intermedia as a suspected vector of Leishmania (Viannia) braziliensis in Bahia State, Brazil. Rev Soc Bras Med Trop 23: 235.

Queiroz RG, Vasconcelos IA, Vasconcelos AW, Pessoa FA, Sousa RN, David JR 1994. Cutaneous leishmaniasis in Ceará state in northeastern Brazil: incrimination of Lutzomyia whitmani (Diptera:Psychodidae) as a vector of Leishmania braziliensis in Baturité municipality. Am J Trop Med Hyg 50: 693-698.

Rangel EF, Azevedo ACR, Andrade CA, Souza NA, Wermelinger ED 1990. Studies on sandfly fauna (Diptera:Psychodidae) in a focus of cutaneous leishmaniasis in Mesquita, Rio de Janeiro State, Brazil. Mem Inst Oswaldo Cruz 85: 39-45.

Rangel EF, Barbosa AF, Andrade CA, Sousa NA, Wermelinger ED 1992. Development of Leishmania (Viannia) braziliensis Vianna, 1911 in Lutzomyia intermedia (Lutz \& Neiva, 1912) (Diptera:Psychodidae:Phlebotominae) under experimental conditions. Mem Inst Oswaldo Cruz 87: 235-238.

Romaña C, Abalos JW 1949. Distribución de flebótomos en la Argentina. An Inst Med Reg 2: 293-302.

Salomón OD 1993. Phlebotominae en un foco de leishmaniasis cutánea en la provincia de Salta. Medicina (Buenos Aires) 53 (Supl. 1): 34-35.

Salomón OD 1997. Phlebotominae Sandflies at a Leishmaniasis Focus in Argentina, $\mathrm{PhD}$ Thesis, Yale University, $167 \mathrm{pp}$.

Salomón OD 1998. Vectores de leishmaniasis. In AC Seijo, OP Larghi, MO Espinosa, M Rivas, M Sabattini (eds), Zoonosis y Enfermedades Emergentes, Asoc Arg Zoonosis, Buenos Aires, p. 264- 267.

Salomón OD, Zaidemberg M 1997. Brote de leishmaniasis cutánea americana (LCD) en Salta, 1993 - III. Aspectos entomológicos. Medicina (Buenos Aires) 57 (Supl. 3): 48-49.

Salomón OD, Travi BL, Segura EL 1995. Note on sandflies associated with a tegumentary leishmaniasis focus in Salta, Argentina, 1988. Rev Inst Med Trop São Paulo 37: 91-92.

Sosa Estani S 1998. Prevalencia de Infección y Factores de Riesgo de la Transmisión de Leishmaniasis en Salta, República Argentina, MSc Thesis, Universidad de Buenos Aires, 120 pp. 
Sosa Estani S, Campanini A, Sinagra A, Luna C, Peralta M, Coutada V, Medina L, Riarte A, Salomón OD, Gómez A, Segura EL 1998. Caracteristicas clínicas y diagnóstico de la leishmaniasis mucocutanea en pacientes de un área endémica de Salta. Medicina (Buenos Aires)58: 685-691.

Sosa Estani S, Salomón D, Gómez A, Segura EL 1993. Prevalencia de leishmaniasis en Salta, Argentina. Medicina (Buenos Aires) 53 (Supl. 1): 78

Spinelli GR, Rossi GC, Rodríguez EA 1999. Further notes on Phlebotominae from Argentina (Diptera: Psychodidae). Rev Soc Entomol Argent 58: 197-200.

Stolf HO, Alencar Marques S, Marques MEA, Yoshida ELA, Dillon NL 1993. Surto de leishmaniose tegumentar americana em Itaporanga, São Paulo (Brasil). Rev Inst Med Trop São Paulo 35: 437-442.

Tolezano JE 1994. Ecoepidemiological aspects of American cutaneous leishmaniasis in the State of São Paulo, Brazil. Mem
Inst Oswaldo Cruz 89: 427-434.

Villafañe R, Richter EE, Soave de Richter L 1988. Análisis Crítico de la Epidemia de Leishmaniasis Años: 1985/87, Provincia de Salta, Dirección General de Epidemiología, Ministerio de Salud Pública, Salta, 25 pp.

Villalonga JF 1963. Leishmaniosis tegumentaria americana: clínica y tratamiento. Rev Fac Med Tucumán 6: 197-208.

Walsh JF, Molyneux DH, Birley MH 1993. Deforestation: effects on vector-borne disease. Parasitology 106 (Suppl.): 55-75.

Young DG, Arias JR 1992. Flebótomos: Vectores de Leishmaniosis en las Américas, Organización Panamericana de la Salud, Cuaderno Técnico 33, OPS-OMS, Washington, 28 pp.

Young DG, Duncan MA 1994. Guide to the identification and geographic distribution of Lutzomyia sand flies in Mexico, the West Indies, Central and South America (Diptera: Psychodidae). Mem Amer Entomol Inst 54: 1-881. 